Our Nature (2011) 9: 100-106

\title{
Potential Use of some Petal Extracts against Xanthomonas campestris pv. campestris
}

\author{
S.K. Bhardwaj ${ }^{1 *}$, S.K. Singla ${ }^{2}$ and R.K. Bhardwaj ${ }^{3}$ \\ ${ }^{1}$ Horticulture Wing, M.D. University, Rohtak- 124 001, India \\ ${ }^{2}$ Divisional Forest Office, Ponta Sahib-173025, India \\ ${ }^{3}$ Department of Chemistry, Dyal Singh College, Karnal-132001, India \\ "E-mail:skbmdu66@gmail.com
}

Received: 12.09.2011, Accepted: 22.11.2011

\begin{abstract}
The aqueous petal-extracts of 20 plants were screened by agar diffusion methods for their antibacterial activity against Xanthomonas campestris pv. campestris, a causal organism of black rot of cabbage and cauliflower. X. campestris pv. campestris was found most sensitive to the petal extracts of Tagetes erecta and Chrysanthemum coronarium. Some of the other plants such as Acacia fernesiana, Anthocephalus cadamba, Bombax malabaricum, Lathyrus odoratus, Rosa damascena and Thevetia nerifolia also showed the inhibitory effect against the test bacteria.
\end{abstract}

Key words: Xanthomonas campestris pv. campestris, antibacterial activity, petal extracts, phytochemicals.

\section{Introduction}

Nature is the foremost physician. Abuse of nature's law upsets the ecosystem leading to occurrence of diseases in plants. Plants, like humans and animals, also get sick, exhibit disease symptoms, and die. Plant diseases are caused by environmental stress, genetic or physiological disorders and infectious agents including viriods, viruses, bacteria, fungi, algae, insects and nematodes etc. Plant diseases of economic crops alone cause $13-20 \%$ annual loss on production representing US $\$ 50 \times 10^{9}$ (James, 1981). In the absence of exact estimates in India, it can safely be assumed that more than $50 \%$ of the others crops loss is due to soil inhabiting microorganisms. Now a days more and more hazardous chemicals are being added in the natural environment in order to maintain the productivity of crops, which enter the food chain through water, soil and air resulting serious harmful affect in human health (Ramachandra and Nagarathna, 2003). According to the survey made by the WHO, more than 50,000 people in developing countries are annually poisoned and 5,000 die as a result of the effects of toxic agents, used in agriculture. In India, 35,000-40,000 tons of hazardous chemicals are sprayed on the crops every year, instead of helping the poor, these chemicals are causing cancer, sterility and death (Das, 1983). To avoid the use of these horrible diseases causing synthetic chemicals, the plants and their product should be utilized to combat phytopathogens. Plants are known to possess various secondary metabolites having antibacterial properties against phytopathogens (Patni et al., 2005; Bhardwaj and Laura, 2008). Therefore, the efforts are underway to search economic and safe phytochemicals, which could be 
utilized for disease control. Thus the object of present study was to exploit the potential of different petals extracts against $X$. campestris pv. campestris for selecting the most potent plants possessing antibacterial activities.

\section{Materials and methods}

The petals of 20 plants mentioned in table 1 were collected from the nursery and horticulture wings. The samples were thoroughly washed with distilled water, dried in dark room and grounded into powder for extract preparation (15 g petals $/ 100 \mathrm{ml}$ water). The bacteria $X$. campestris pv. campestris (MTCC No. 2286) used for the study was procured from the IMMTC, Chandigarh. The culture was maintained at $4^{\circ} \mathrm{C}$ on nutrient agar medium with periodic sub-culturing.

\section{Antibacterial tests}

Plants extracts was prepared by brewing in boiling water for 15 minutes followed by centrifugation at $12000 \mathrm{rpm}$ for $15 \mathrm{~min}$. The supernatants were collected in screw-capped vials and sterilized by autoclaving for 15 min at $121^{\circ} \mathrm{C}$ and the $\mathrm{pH}$ was adjusted to 7.0 (Toda et al., 1989).

The assay for antibacterial activity of each plant part extract was tested by agar diffusion method by slightly modifying the methods of Toda et al. (1989). Bacterial suspensions were cultured in peptone water for $6-8 \mathrm{~h}$ and $0.2 \mathrm{ml}$ of this culture was spread on Mueller-Hinton agar in petridishes. Wells ( $8 \mathrm{~mm}$ diameter) were cut in agar plates and were filled $0.1 \mathrm{ml}$ of $15 \%$ plants extracts. The plates inoculated with $X$. campestris pv. campestris were incubated at $30 \pm 1{ }^{\circ} \mathrm{C}$. The resulting zone of inhibition was measured after $24 \mathrm{~h}$. Each combination of isolates and antimicrobial agent was repeated three times. The isolate which showed clear zone of inhibition more than $12 \mathrm{~mm}$ including the $8 \mathrm{~mm}$ well size were considered sensitive and those with less than $12 \mathrm{~mm}$ as resistant.

Minimum Inhibitory Concentration (MIC) was determined by the agar dilution method (Koneman et al., 1988) where plants extract concentration ranged from $0.25-3.0 \%$. MIC was determined as the lowest concentration that prevented visible growth of microorganisms after incubation for $40 \mathrm{~h}$ at $30 \pm 1^{\circ} \mathrm{C}$.

\section{Results}

The activity of the plant-extracts against the bacterial growth of $X$. campestris pv. campestris is presented in table 2 . It was observed that out of 20 plants parts extracts tested, nine plant extracts showed inhibitory effect against the bacterial growth of $X$. campestris pv. campestris. The maximum inhibitory effect was shown by petals extract of Tagetes erecta $(24.0 \mathrm{~mm})$ and Chrysanthemum coronarium $(23.50 \mathrm{~mm})$. The test bacterium was less inhibited by petals extract of Rosa damascena (13.5 $\mathrm{mm})$, Acacia fernesiana (11.5 $\mathrm{mm})$, Thevetia nerifolia $(11.5 \mathrm{~mm})$, Bombax malabaricum (11.0 $\mathrm{mm})$, Anthocephalus cadamba $(10.5 \mathrm{~mm})$ and Lathyrus odoratus $(10.5 \mathrm{~mm})$. The rest eleven plants samples did not show antibacterial effect against the test bacteria.

In general the Minimum Inhibitory Concentrations (MIC) of various plants extracts was observed 2.0\%, while Anthocephalus cadamba and Bombax malabaricum showed $3.0 \% \quad$ MIC. Chrysanthemum coronarium and Tagetes erecta showed $1.0 \%$ MIC for the test bacteria $X$. campestris pv. campestris (Tab. 2). 
S.K. Bhardwaj, S.K. Singla and R.K. Bhardwaj/Our Nature (2011) 9:100-106

Table 1. Common names and families of plants used in experiment.

\begin{tabular}{|c|c|c|c|c|c|}
\hline$\overline{\mathbf{S N}}$ & Botanical name & Common name & Name of family & Distribution & $\begin{array}{l}\text { Traditional uses of } \\
\text { plants }\end{array}$ \\
\hline 1 & Acacia fernesiana (L.) & Ghand Babul & Mimosaceae & Tropics & $\begin{array}{l}\text { Flowers are a source of } \\
\text { essential oil used in } \\
\text { perfumery (Usher, } \\
\text { 1971). }\end{array}$ \\
\hline 2 & $\begin{array}{l}\text { Anthocephalus cadamba } \\
\text { (Mig.) }\end{array}$ & Kadam & Rubiaceae & Tropical Asia & $\begin{array}{l}\text { The bark is used as a } \\
\text { tonic and reduces fever } \\
\text { (Usher, 1971). }\end{array}$ \\
\hline 3 & Bombax malabaricum DC & Semul & Bombacaceae & Tropical Asia & $\begin{array}{l}\text { The wood is a source of } \\
\text { cellulose, resin; root } \\
\text { and bark are used as an } \\
\text { emetic. The gum is } \\
\text { demulcent and used to } \\
\text { treat diarrhea (Usher, } \\
\text { 1971). }\end{array}$ \\
\hline 4 & Cassia fistula (L.) & Amaltash & Caesalpiniaceae & Tropical Africa & $\begin{array}{l}\text { The pulp of pods is } \\
\text { used as a laxative } \\
\text { (Usher, 1971). }\end{array}$ \\
\hline 5 & Cassia nodusa (Ham.) & Gulabi Amaltash & Caesalpiniaceae & West Malaysia & $\begin{array}{l}\text { The wood is used for } \\
\text { posts and tool handles } \\
\text { while roots are used as } \\
\text { soap for washing } \\
\text { clothes (Usher, 1971). }\end{array}$ \\
\hline 6 & Cassia siama (Vahl.) & Siama & Caesalpiniaceae & $\begin{array}{l}\text { India to } \\
\text { Indonesia }\end{array}$ & $\begin{array}{l}\text { The wood is used for } \\
\text { heavy construction } \\
\text { work, mine props and } \\
\text { as a fuel (Usher, 1971). }\end{array}$ \\
\hline 7 & Callistemon lanceolatus & Bottle Brush & Myrtaceae & $\begin{array}{l}\text { Australlia, } \\
\text { India }\end{array}$ & $\begin{array}{l}\text { Leaves are a Tea } \\
\text { substitute and have a } \\
\text { delightfully refreshing } \\
\text { flavour (Cribb, 1976), } \\
\text { tan dye is obtained } \\
\text { from the leaves (Grae, } \\
\text { 1974). }\end{array}$ \\
\hline 8 & Cedrella toona Roaxb. & Toon & Meliaceae & $\begin{array}{l}\text { India to } \\
\text { Australia }\end{array}$ & $\begin{array}{l}\text { The flowers are the } \\
\text { sources of red and } \\
\text { yellow dyes and wood } \\
\text { used for furniture, } \\
\text { house building, tea } \\
\text { chests, oil casks, and } \\
\text { cigar boxes (Usher, } \\
\text { 1971). }\end{array}$ \\
\hline 9 & $\begin{array}{l}\text { Chrysanthemum coronarium } \\
\text { (L.) }\end{array}$ & Guldawadhi & Compositae & $\begin{array}{l}\text { Asia, Africa, } \\
\text { Mediterranean }\end{array}$ & $\begin{array}{l}\text { The young seedlings } \\
\text { are cooked as a } \\
\text { vegetable in China and } \\
\text { Japan (Usher, 1971). }\end{array}$ \\
\hline 10 & Delphinium ajacis (L.) & Larkspur & Ranunculaceae & $\begin{array}{l}\text { Europe, } \\
\text { Mediterranean }\end{array}$ & $\begin{array}{l}\text { A tincture of the dried } \\
\text { ripe seeds is used }\end{array}$ \\
\hline
\end{tabular}


S.K. Bhardwaj, S.K. Singla and R.K. Bhardwaj/Our Nature (2011) 9:100-106

Table 1-Contd....

\begin{tabular}{|c|c|c|c|c|}
\hline & & & & $\begin{array}{l}\text { medicinally as a } \\
\text { parasiticide (Usher, } \\
\text { 1971). }\end{array}$ \\
\hline $\begin{array}{l}11 \text { Jacranda mimosaefolia } \\
\text { (D.Don.) }\end{array}$ & Nili Gulmohar & Bignoniaceae & $\begin{array}{l}\text { Tropical South } \\
\text { America }\end{array}$ & $\begin{array}{l}\text { The wood is used in } \\
\text { general carpentry } \\
\text { (Usher, 1971). }\end{array}$ \\
\hline $\begin{array}{l}12 \text { Lagerstroemia flosreginae } \\
\text { (Retz.) }\end{array}$ & Jarul & Lythraceae & Malaysia & $\begin{array}{l}\text { The wood is insect } \\
\text { resistant and used for } \\
\text { house building, } \\
\text { flooring, bridges and } \\
\text { railways sleepers } \\
\text { (Usher, 1971). }\end{array}$ \\
\hline 13 Lantana camera $(\mathrm{L})$. & Ghaneri & Verbenaceae & $\begin{array}{l}\text { Tropical } \\
\text { America }\end{array}$ & $\begin{array}{l}\text { A decoction of the } \\
\text { leaves is used locally as } \\
\text { a tonic and stimulant } \\
\text { (Usher, 1971). }\end{array}$ \\
\hline 14 Lathyrus odoratus L. & Sweet Pea & Leguminosae & South Europe & $\begin{array}{l}\text { An essential oil is } \\
\text { extracted from flowers } \\
\text { and used in perfumery } \\
\text { (Usher, 1971). }\end{array}$ \\
\hline 15 Nerium indicum (Mill.) & Red Kaner & Apocynaceae & Tropical India & $\begin{array}{l}\text { A poultice of root is } \\
\text { used against ringworm; } \\
\text { the flowers are used for } \\
\text { perfume and produce a } \\
\text { good honey (Usher, } \\
\text { 1971). }\end{array}$ \\
\hline 16 Nerium oleander $(\mathrm{L})$. & White Kaner & Apocynaceae & Mediterranean & $\begin{array}{l}\text { The roots are used in } \\
\text { criminal poisoning and } \\
\text { to exterminate rats } \\
\text { (Usher, 1971). }\end{array}$ \\
\hline 17 Nychtenthus arbortristis (L.) & Har Sringar & Verbenaceae & India & $\begin{array}{l}\text { The leaves yield a } \\
\text { bright yellow dye } \\
\text { (Usher, 1971). }\end{array}$ \\
\hline 18 Rosa damascena (Mill.) & Gulab & Rosaceae & $\begin{array}{l}\text { Balkans and } \\
\text { Asia Minor }\end{array}$ & $\begin{array}{l}\text { The oil extracted from } \\
\text { flowers is used in } \\
\text { perfumery and for } \\
\text { flavouring (Usher, } \\
\text { 1971). }\end{array}$ \\
\hline 19 Tagetes erecta $(\mathrm{L})$. & Gendha & Compositae & $\begin{array}{l}\text { Mexico, Old } \\
\text { and New } \\
\text { World, India }\end{array}$ & $\begin{array}{l}\text { The flowers are used as } \\
\text { source of yellow dye; } \\
\text { decoction of flowers } \\
\text { and leaves is used to } \\
\text { treat intestinal worms, } \\
\text { stomach upsets and to } \\
\text { control menstruation } \\
\text { (Usher, 1971). }\end{array}$ \\
\hline 20 Thevetia nerifolia (Juss.) & Pili Kaner & Apocynaceae & $\begin{array}{l}\text { Tropical } \\
\text { America, West } \\
\text { Indies }\end{array}$ & $\begin{array}{l}\text { The bark is used to } \\
\text { reduce fevers (Usher, } \\
\text { 1971). }\end{array}$ \\
\hline
\end{tabular}


S.K. Bhardwaj, S.K. Singla and R.K. Bhardwaj/Our Nature (2011) 9:100-106

Table 2. Anti-bacterial activity and minimum inhibitory concentrations of petal-extracts against $X$. campestris pv. campestris

\begin{tabular}{|c|c|c|c|c|c|c|}
\hline \multirow{2}{*}{ SN Plant species } & \multirow{2}{*}{$\begin{array}{c}\text { Zone of inhibition } \\
(\mathrm{mm})^{*}\end{array}$} & \multicolumn{5}{|c|}{ Minimum inhibitory conc. (\%) } \\
\hline & & 0.25 & 0.5 & 1.0 & 2.0 & 3.0 \\
\hline 1 Acacia fernesiana (L.) & $11 . .50 \pm 1.24$ & + & + & + & - & - \\
\hline 2 Anthocephalus cadamba (Mig.) & $10 . .50 \pm 2.15$ & + & + & + & + & - \\
\hline 3 Bombax malabaricum D.C. & $11.00 \pm 1.78$ & + & + & + & + & - \\
\hline 4 Cassia fistula (L.) & - & NT & NT & NT & NT & NT \\
\hline 5 Cassia nodusa (Ham.) & - & NT & NT & NT & NT & NT \\
\hline 6 Cassia siama (Vahl.) & - & NT & NT & NT & NT & NT \\
\hline 7 Callistemon lanceolatus & - & NT & NT & NT & NT & NT \\
\hline 8 Cedrella toona Roxb. & - & NT & NT & NT & NT & NT \\
\hline 9 Chrysanthemum coronarium (L.) & $23 . .50 \pm 0.35$ & + & + & - & - & - \\
\hline 10 Delphinium ajacis & - & NT & NT & NT & NT & NT \\
\hline 11 Jacranda mimosaefolia (D.Don.) & - & NT & NT & NT & NT & NT \\
\hline 12 Lagerstroemia flos-reginae (Retz.) & - & NT & NT & NT & NT & NT \\
\hline 13 Lantana camera $(\mathrm{L})$. & - & NT & NT & NT & NT & NT \\
\hline 14 Lathyrus odoratus L. & $10 . .50 \pm 0.84$ & + & + & + & - & - \\
\hline 15 Nerium indicum (Mill.) & - & NT & NT & NT & NT & NT \\
\hline 16 Nerium oleander $(\mathrm{L})$. & - & NT & NT & NT & NT & NT \\
\hline 17 Nychtenthus arbor-tristis (L.) & - & NT & NT & NT & NT & NT \\
\hline 18 Rosa damascena (Mill.) & $13 . .50 \pm 2.47$ & + & + & + & - & - \\
\hline 19 Tagetes erecta $(\mathrm{L})$. & $24.0 \pm 0.26$ & + & + & - & - & - \\
\hline 20 Thevetia nerifolia (Juss.) & $11.00 \pm 2.25$ & + & + & + & - & - \\
\hline
\end{tabular}

* Mean \pm SD, NT= Not tested.

\section{Discussion}

Among the different plants screened, petal extracts of Tagetes erecta and Chrysanthemum coronarium showed maximum inhibitory activity against $X$. campestris pv. campestris (Tab. 2). Petal extract of Tagetes erecta was observed to show strong inhibitory effect against the bacterial growth of $X$. campestris (Tab. 2), which might be due to several antibacterial substances present in the plant sample, some phytochemicals. Various medicinal and antifungal properties of Tagetes erecta has been reported in literatures (Usher, 1971; Singh and Sharma, 1978; Baslas and Singh, 1981; Pandey, 1993), these correlate with our results. Petal extract of Chrysanthemum coronarium was observed to show inhibitory effect against the bacterial growth of $X$. campestris, which might be due various antimicrobial substances present in the plant sample, some phytochemicals such as coumarins, flavonoids and alcoholic soluble phenols. Petal extract of Rosa damacena was observed to show inhibitory effect against the test bacterial growth which might be due to various antimicrobial substances present in the plant sample, some phytochemicals like catechol, anthoxanthins, anthocynin, rutin, flavane and gallic acid, were found registered in literatures by several workers (Nicolls, 1970; Shekhawat and Prasad, 1971; Dixit et al., 1975). The antimicrobial activities of plants studied have also been found registered in various literature i.e., Acacia fernesiana (Usher, 1971), Anthocepholus cadamba (Dilip and Bikash, 2004), Thevetia 
S.K. Bhardwaj, S.K. Singla and R.K. Bhardwaj/Our Nature (2011) 9:100-106

nereifolia (Usher, 1971; Pandey, 1993; Kurucheve et al., 1997).

The test bacteria $X$. campestris pv. campestris was observed sensitive to a very low concentration $(1.0 \%)$ of the aqueous extracts of Chrysanthemum coronarium and Tagetes erecta. The MIC was found slightly higher in case of petal extract of Rosa damascena, Acacia fernesiana, Thevetia nerifolia and Lathyrus odoratus against the test bacterium while Anthocephalus cadamba and Bombax malabaricum were observed to show inhibitory effect against the $X$. campestris pv. campestris at higher concentrations as compared to others tested plants samples (Tab. 2). The variations in the MIC might be due to differences in phytochemicals composition (Owuor et al., 1986; Toda et al., 1989).

Since the extracts of Acacia fernesiana, Anthocephalus cadamba, Bombax malabaricum, Chrysanthemum coronarium and Lathyrus odoratus used in this study have not been tested before as inhibitor of phytopathogenic bacteria, therefore, this may be a new report. The presence of various secondary metabolites such as alkaloids, quaternary alkaloids, coumarins, flavanoids, steroids/terpenoids, phenols etc., have been reported in the various plants extracts (Aswal et al., 1984; Abraham et al., 1986; Chopra et al., 1992) which may be responsible for the antibacterial properties of the plants studied.

\section{References}

Abraham, Z., D.S. Bhakuni, H.S. Garg, A.K. Goel, B.N. Mehrotra and G.K. Patnaik 1986. Screening of Indian plants for biological activity, Part X11. Indian Journal Experimental Biology 24: 48-68.

Aswal, B.S., D.S. Bhakuni, A.K. Goel, K. Kar and B.N. Mehrotra 1984. Screening of Indian plants for biological activity; Part X1. Indian Journal Experimental Biology 22: 487-504.

Baslas, R.K. and A.K. Singh 1981. Chemical examination of essential oil from leaves of Tagetes erecta Linn. Journal Indian Chemical Society LVIII: 104.

Bhardwaj, S.K. and J.S. Laura 2008. Antibacterial activity of some plant-extracts against pathogenic bacteria, Erwinia carotovora subsp. carotovora. Potato Journal 35(1-2): 72-77.

Chopra, R.N., S.L. Nayer and I.C. Chopra 1992. Glossary of Indian medicinal plants. $3^{\text {rd }}$ ed. Council of Scientific and Industrial Research, New Delhi, India. 246p.

Das, T. 1983. Death in the garb of pesticides. The Hindustan Times. Dec. 30, 1983.

Dilip, K. and D. Bikash 2004. Traditional medicines used by the Sonowal Kacharis of Brahmaputra valley, Assam. Plant Archives 4: 77-80.

Dixit, S.N., S.C. Tripathi and R.R. Upadhyay 1975. The antifungal substance of rose flowers (Rosa indica). Economic Botany 30: 371-374.

James, W.C. 1981. Estimated losses of crops from plant pathogens. In: Hand book of pest management in agriculture (Ed. D. Primentel), Vol. 1. CRC Press, Boca Raton. Fl. USA pp.7994.

Koneman, E.W., S.D. Allen, V.R. Dowell, W.M. Janda, H.M. Sommers and W.C. Winn 1988. The interobacteriaceae. In: Color atlas and textbook of diagnostic microbiology (Ed. E.W. Koneman). J.B. Lippinacott Company, East Washington Square, Philadelphia, Pennsylvania, USA. pp. 89156.

Kurucheve, V., J.G. Ezhilan and J. Jayaraj 1997. Screening of higher plants for fungitoxicity against Rhizoctonia solani in vitro. Indian Phytopathology 50(2): 235-241.

Nicolls, J.M. 1970. Antifungal activity in Passiflora sp. Annal Botany 34: 229-237.

Owuor, P.O., H. Horita, T. Tsushita and T. Murai 1986. Comparison of the chemical compositions of black teas from main black tea producing parts of the world. Tea 7: 71-78.

Pandey, B.P. 1993. Taxonomy of angiosperms. S. Chand and Co., New Delhi, India. 642p. 
S.K. Bhardwaj, S.K. Singla and R.K. Bhardwaj/Our Nature (2011) 9:100-106

Patni, C.S., S.J. Kolte and R.P. Awasthi 2005. Effect of some botanicals on management of Alternaria Blight and White Rust of Mustard. Journal of Plant Disease Science 1(1): 58-62.

Ramachandra, T.V. and A.V. Nagarathna 2003. Ecodegradation, biodiversity and health. (Eds. B.N. Pandey. 2002; Daya Publ. Delhi, 335p). Book reviews. Current Science 85(9-10): 1368-1369.

Shekhawat, P.S. and R. Parsad 1971. Antifungal properties of some plant extracts: inhibition of spore germination. Indian Phytopathology 24: 800.

Singh, L. and M. Sharma 1978. Antifungal properties of some plant extracts. Geobios 5: 49-53.

Toda, M., S. Okubo, R. Hiyoshi and T. Shimamura 1989. The bactericidal activity of tea and coffee. Letters in Applied Microbiology 8: 123-25.

Usher, G. 1971. A dictionary of plants used by man. CBS Pub. and Distr. Print Orient offset, Delhi, India. 619p. 